\title{
Evaluation of heat sources in settlement project in the municipality of Nova Ubiratã, Mato Grosso state
}

\author{
Vanusa de Souza Pacheco Hoki ${ }^{1,2 *}$, Luciana Sanches ${ }^{1}$, Ian Felipe Cabral ${ }^{1,3}$, \\ Roberta Daniela de Souza Lauxen da Silva ${ }^{2}$, Camylla Kerly Pereira Mariano ${ }^{l}$
}

\footnotetext{
${ }^{1}$ Universidade Federal de Mato Grosso (UFMT), Cuiabá, Mato Grosso, Brazil

${ }^{2}$ University of Cuiabá (UNIC), Cuiabá, Mato Grosso, Brazil

${ }^{3}$ Environmental Emergencies Battalion (BEA), Cuiabá, Mato Grosso, Brazil

*e-mail: vanusahoki@gmail.com; 1 sanches@ @otmail.com; agro.ifc@ gmail.com; roberta.engenhariaambiental@gmail.com; camylla_kerly@hotmail.com
}

\begin{abstract}
The Nova Ubiratã municipality is considered the 3rd largest grain producer in the State of Mato Grosso, Brazil, with more than 600 thousand hectares dedicated to soybean, corn, cotton and other crops. Before the agribusiness, from the 90's, the federal agency named as Instituto Nacional de Colonização e Reforma Agrária (INCRA)) installed federal settlements (PAs) known as: Piratininga, Santa Terezinha II, Boa Esperança I, II and III and Cedro Rosa, with a total area of 77238 ha and 915 settled families in 2017. The diagnosis of hot spots in the PAs was the beginning of a proposal of Integrated Fire Management (MIF) plan, and its success depends on the size of the PAs, geographic location and isolation, human density and environmental activities/pressures, capacity (firefighters, equipment), local fire brigade training and community support. In this context, this study aimed to analyze the heat sources obtained by remote sensing in the federal settlements (PAs) in relation to the territorial extension of the municipality of Nova Ubiratã, in the period of the dry season between May and October, in the years 2015 to 2018. For this purpose, we downloaded data from the Instituto Nacional de Pesquisas Espaciais (INPE), heat sources detected by the AQUA/MODIS "Satellite of reference" with a spatial resolution of $1 \mathrm{~km}$, we carried out spatial. Our results indicated that in the dry season the PAs with $6 \%$ of the rural area of the municipality contributed with up to $28 \%$ of the total of hot spots detected in the municipality between the years 2015 to 2018 . We concluded that the hot spots in the federal settlements and in the municipality results from the use of fire for pasture and agricultural management. Our finding can assist the management of government projects to promote operational actions of monitoring, prevention, firefighting and in the provision of areas prone to fire hazard.
\end{abstract}

Keywords: fires, hot spots, soil management, MODIS product, farmer 